\title{
Border Disease Virus Transmitted to Sheep and Cattle by a Persistently Infected Ewe: Epidemiology and Control
}

\author{
By U. Carlsson and K. Belák
}

Department of Cattle and Sheep Diseases, Swedish University of Agricultural Sciences, Uppsala and National Veterinary Institute, Department of Pathology, Uppsala, Sweden.

\begin{abstract}
Carlsson, U. and K. Belák: Border disease virus transmitted to sheep and cattle by a persistently infected ewe: Epidemiology and control. Acta vet. scand. 1994, 35, 79-88. In a Swedish sheep flock comprising 202 ewes and 13 rams, a pair of twin lambs born in the spring of 1990 demonstrated signs of border disease (BD) and were persistently infected (PI) with border disease virus (BDV). Investigation showed that BDV had been introduced in the preceding tupping period 5-6 months earlier by a bought-in ewe which, on the basis of immunoperoxidase- and polymerase chain reaction techniques, was shown to be PI with BDV. Only 7 of the ewes, all of which had been in close contact with the PI ewe, seroconverted during the subsequent gestation. Apart from the PI twin lambs the losses caused by BDV were restricted to 2 barren ewes. The twin lambs, the PI ewe and lambs from the other 4 ewes that seroconverted were removed from the flock. The flock was thereafter free from an ongoing infection with BDV as shown by the absence of seroconversion.

In addition, 5 heifers in late pregnancy most probably seroconverted to bovine virus diarrhoea virus (BVDV) when kept in close contact with the same PI ewe during the winter of 1989-90. When these heifers were reintroduced to the BVDV-free dairy herd from which they originated, their serum antibody titres ranged between 1:250 and 1:1250. Neither these heifers - nor therr calves - caused any spread of the infection in the herd, as indicated by the absence of seroconversion in 70 cows.

The present investigation shows that in the control of both BDV in sheep and BVDV in cattle, it is important to ensure that the risk of transmission of pestivirus between the 2 species is minimized.
\end{abstract}

$B D V ; B V D V ;$ interspecies transmission.

\section{Introduction}

Border disease (BD), a congenital disorder of sheep, was first described in 1959 (Hughes et al. 1959). A BDV infection in pregnant ewes during early- or mid-gestation can result in fetal death with resorption, mummification, abortion, or stillbirth, but may also result in the birth of clinically affected or even apparently healthy lambs that are persistently in- fected (PI) with BDV (Terpstra 1985). These lambs can develop normally and reach mature age. Apart from being potent lateral transmitters of the virus, PI ewes infect their offspring in utero in consecutive years (Barlow et al. 1980, Woldehiwet \& Nettleton 1991). Postnatal BDV infections are usually subclinical.

Due to their antigenic relationship, border disease virus (BDV), bovine virus diarrhoea 
virus (BVDV) and hog cholera virus (HCV) are all classified in the pestivirus genus within the family Flaviviridae (Francki et al. 1991). BVDV has been shown to readily infect sheep under both experimental and natural conditions (Carlsson 1991). Although sequence analysis data from a recent study suggested that BVDV and BDV possibly were 2 distinct viruses (Berry et al. 1992), it remains a possibility that they have a common origin and that changes in epitope expression might arise during passages in different species.

In Sweden, the primary cause of BD outbreaks has been shown to be contact between cattle PI with BVDV and susceptible sheep (Carlsson 1991). Interspecies transmission between cattle and sheep has been suggested previously (French et al. 1974, Physick-Sheard et al. 1980, Nettleton 1988). Recently it was also demonstrated that goats, vaccinated with a pestivirus-contaminated orf vaccine, transmitted BDV/BVDV to sheep and cattle (Loken et al. 1991). Other sources of infection to sheep are bought-in PI animals or, pregnant antibody positive ewes carrying PI fetuses. Transmission from transiently viraemic sheep or cattle is probably less important, although it can occur (Moerman et al. 1993). Virus transmission by blood-feeding flies has also been suggested (Tarry et al. 1991).

The present paper reports the consequences of introducing a ewe PI with BDV into a flock with pregnant ewes and heifers. The infection was eradicated and control strategies to avoid the infection are discussed.

\section{Materials and methods}

\section{Flock history}

The flock comprised 202 ewes and 13 rams and was being used for research purposes to compare growth and slaughter traits in crossbred lambs (Swedish landrace, Leicester and
Texel). The housing and tupping period started in October 1989 and the sheep were let out on pasture in May.

Five ewe lambs (designated A1-A5) from another farm were kept on the same pasture as lambs from the flock subjected to this investigation in the late summer of 1989. These 5 lambs and other lambs on the pasture were introduced to the flock in October 1989. In late 1988 a bull calf PI with BVDV had been detected on the farm where the lambs A1-A5 were born. Contact between this PI calf and the ewes that gave birth to lambs A1-A5 possibly occurred in the autumn of 1988.

Five heifers in late pregnancy, originating from a closed dairy herd, were housed together with the sheep flock during JanuaryMarch 1990. All cattle in this herd had been found to be free from BVDV antibodies in serum when tested in the autumn of 1989. During the mentioned 3-month period there was close contact between the heifers, the bought-in ewes (A1-A5) and 20 ewes from the flock, all of which were thought to be pregnant. The 5 heifers were returned to the dairy herd at the end of March, 1 month prior to calving.

In the sheep flock, no illhealth was recorded and no abortions occurred during the gestation period, but 8 ewes, a few more than usual, were found to be barren. However, a pair of twin lambs, born in April 1990, were trembling violently at birth. When they were 2 days old, the twins and their dam were bloodsampled and tested for the presence of BDV antibodies. Both lambs, together with the dam, were removed from the flock and isolated. The nervous signs present at birth gradually became less marked and at about 2 months of age the twins were admitted to the Clinic of Department of Cattle and Sheep Diseases, Swedish University of Agricultural Sciences, Uppsala, for further investigation. 


\section{Flock and herd investigation}

In April 1990 the entire sheep flock was blood-sampled and tested for the presence of antibodies to BDV. Since this was a flock used for research, sera were available from the time before breeding in October 1989 and ewes that had seroconverted to BDV during the gestation period of $1989-90$ could therefore be detected. During this period 10 ewes had died or had been culled. The sheep were again tested for the presence of antibodies both in the spring and autumn of 1991. Rams as well as the lambs from ewes that seroconverted in 1989-90 were tested for the presence of both antibodies and BDV.

The 5 bought-in yearling lambs (A1-A5) which were raised separately together with their own lambs after lambing in the spring of 1990 were also investigated for serum antibodies and BDV.

In order to determine the persistence of the antibody titres, 13 ewes in the flock were blood-sampled at 6-month intervals for a period of 2-31/2 years, beginning in October 1989. In July 1990, all 70 cows in the cattle herd were tested for antibodies to BVDV. The 5 heifers as well as 3 of their 3-month old calves were also tested for their antibody titres to BVDV.

\section{Serological examinations}

An enzyme-linked immunosorbent assay (SVANOVA Ubitech AB, Uppsala, Sweden) was used for detection of antibodies to BVDV (Juntti et al. 1987) and BDV (Lundén et al. 1992). Some sera (Table 1) were tested in 5fold dilutions, starting from 1:10 to 1:1250.

\section{Virological examinations}

Immunoperoxidase technique. The presence of BDV in buffy coat and/or sera was tested by inoculation on cultures of embryonic bovine turbinate cells. After incuba- tion for 4 days the cultures were examined for cytopathic effect and the presence of BDV was determined by an indirect immuno-peroxidase (IPX) technique using a polyclonal antiserum to BVDV (Meyling 1984).

Polymerase chain reaction technique. Polymerase chain reaction (PCR) technique was applied for the detection of BDV/BVDV viral RNA in serum and buffy coat from 3 sheep (Table 2). Primers and probes were selected from viral genome coding for the $\mathrm{p} 80$ polypeptide of the cytopathic BVDV-strain NADL (Belák \& Ballagl-Pordány unpublished results, Belák \& Ballagi-Pordány 1991). Immunohistochemical examinations. Tissues from 3 sheep (Table 2) were examined with the peroxidase-antiperoxidase (PAP) technique (Belák et al. 1989).

BVDV antigens were demonstrated in OmniFix (Zymed Laboratories Inc., San Francisco, U.S.A.) fixed, paraffin-embedded tissue sections using a cocktail of 4 monoclonal antibodies, MAbs (kindly provided by Dr. Moennig, Hannover, Germany). The MAbs CA3, CA34 and CT6 were raised against different epitopes on the major glycoprotein of BVDV (gp 53) and C42 is specific for BVDV viral protein $\mathrm{p} 125 / \mathrm{p} 80$.

\section{Patho-anatomical examinatıons}

The trembling twin lambs and the ewe A3 underwent gross post-mortem examination. Routine bacteriological examinations were carried out. The brains and spinal cords from the twins were fixed in $10 \%$ formol saline and paraffin-embedded according to routine histological procedure. Sections were stained with haematoxylin-eosin and examined by light microscopy.

\section{Results}

Investigation of sheep flock

The serological screening of 192 sheep re- 
Table 1. BDV-antibody titres determined by a BVDV-ELISA in 24 ewes followed by an outbreak of border disease.

\begin{tabular}{|c|c|c|c|c|c|c|c|c|}
\hline \multirow{2}{*}{$\begin{array}{l}\text { Ewe } \\
\text { no }\end{array}$} & \multirow{2}{*}{ Born } & \multirow{2}{*}{$\begin{array}{l}1989 \\
\text { Oct }\end{array}$} & \multicolumn{2}{|c|}{1990} & \multicolumn{2}{|c|}{1991} & \multirow{2}{*}{$\begin{array}{r}1992 \\
\text { Feb }\end{array}$} & \multirow{2}{*}{$\begin{array}{l}1993 \\
\text { Feb }\end{array}$} \\
\hline & & & Apr & Oct & Apr & Oct & & \\
\hline 1160 & 1981 & $<10$ & 250 & - & - & - & - & - \\
\hline 217 & 1982 & $<10$ & 50 & - & - & - & - & - \\
\hline 221 & 1982 & $<10$ & 250 & - & - & - & - & - \\
\hline $230 \diamond$ & 1982 & $<10$ & 50 & - & - & - & - & - \\
\hline 443 & 1984 & $<10$ & 50 & - & - & - & - & - \\
\hline $902 *$ & 1989 & $<10$ & $\geq 1250$ & 250 & 250 & 250 & 250 & - \\
\hline 912 & 1989 & $<10$ & 250 & 250 & 250 & 250 & 250 & - \\
\hline 905 & 1989 & 250 & 250 & 250 & 250 & 250 & 250 & 250 \\
\hline 909 & 1989 & $\geq 1250$ & $\geq 1250$ & - & - & - & - & - \\
\hline 915 & 1989 & 250 & 250 & - & - & - & - & - \\
\hline 920 & 1989 & $\geq 1250$ & 250 & 250 & 250 & 250 & 250 & 250 \\
\hline 927 & 1989 & 50 & $<10$ & - & - & - & - & - \\
\hline 930 & 1989 & 250 & 250 & - & - & - & - & - \\
\hline 931 & 1989 & 250 & 250 & 250 & 250 & 250 & 250 & 50 \\
\hline 938 & 1989 & 250 & 250 & 250 & 250 & 250 & 250 & - \\
\hline 943 & 1989 & $\geq 1250$ & $\geq 1250$ & $\geq 1250$ & $\geq 1250$ & $\geq 1250$ & $\geq 1250$ & 250 \\
\hline 307 & 1983 & 50 & 10 & - & - & - & - & - \\
\hline 504 & 1985 & 50 & 50 & 50 & 50 & 50 & 50 & - \\
\hline 512 & 1985 & 250 & 250 & 250 & 250 & 250 & 250 & - \\
\hline 513 & 1985 & 250 & 50 & 50 & 50 & 50 & 50 & - \\
\hline 524 & 1985 & 50 & 50 & 50 & 50 & 50 & 50 & - \\
\hline 538 & 1985 & 50 & 10 & 10 & 10 & 10 & 10 & - \\
\hline 638 & 1986 & 10 & 10 & - & - & - & - & - \\
\hline 871 & 1988 & - & 50 & 50 & 50 & 50 & 50 & - \\
\hline
\end{tabular}

- = not tested.

$\diamond$ Ewes 116 and 230 were barren.

* Ewe 902 gave birth to 2 BD-affected lambs in the spring of 1990.

vealed that 16 animals, of which 9 were ewe lambs and 7 were ewes 3 years or older, had detectable antibodies to BDV before tupping in October 1989. In April 1990, 23 sheep, including the previously positive ewes, proved antibody-positive and accordingly 7 ewes seroconverted during the gestation period of 1989-90. Out of these 7 ewes, 2 were barren and 4 produced 10 normal offspring, all of which were tested for the presence of BDV in serum and buffy coat. At an age of 6 months, all 10 lambs were seronegative to BDV and none was found to be persistently infected.
The seventh ewe that seroconverted gave birth to the 2 BD-affected lambs (Table 1).

All rams except 1 were tested seronegative and none was found to be infected with BDV. During the tupping period the seropositive ram had been placed with ewes A1-A5. According to the screenings performed in 1991, no further sheep had seroconverted.

The BDV-antibody titres studied in 13 ewes (Table 1) fell over a period of $2 \frac{1}{2}$ years by $1 \mathrm{ti}$ tre step in 4 ewes, whereas in the remaining 9 the titre remained constant. This phenomenon was observed irrespective of whether the 
Table 2. Results from different technıques used to detect BDV antıgens in serum, buffy coat and different organs in PI sheep.

\begin{tabular}{|c|c|c|c|c|}
\hline $\begin{array}{l}\text { Material } \\
\text { examined }\end{array}$ & $\begin{array}{l}\text { Technique } \\
\text { used }\end{array}$ & $\begin{array}{l}\text { Twin* } \\
\text { I }\end{array}$ & $\begin{array}{l}\text { Twin** } \\
\text { II }\end{array}$ & $\begin{array}{l}\text { Ewe*** } \\
\text { A3 }\end{array}$ \\
\hline Parotıd & PAP & + & + & - \\
\hline Spleen & PAP & - & n.e. & - \\
\hline Esophagus & PAP & n.e. & n.e. & - \\
\hline Lung & PAP & - & + & - \\
\hline Kıdney & PAP & n.e. & n.e. & - \\
\hline Tonsil & PAP & n.e. & n.e. & - \\
\hline Brain & PAP & + & + & + \\
\hline Thyroidea & PAP & + & + & + \\
\hline Ileum & PAP & - & - & - \\
\hline Thymus & PAP & - & - & - \\
\hline Uterus & PAP & n.e & n.e. & - \\
\hline Serum & IPX & $-(2 \mathrm{~d}.) \mathrm{a}$ & $-(2 \mathrm{~d})$. & $-\left(\begin{array}{ll}1 & 1 / 2 \\
y\end{array}\right)$ \\
\hline Buffy coat & IPX & $+(5 \mathrm{w})$. & $+(5 \mathrm{w})$. & -(1 1/2 y. $)$ \\
\hline Buffy coat & IPX & $+(8 \mathrm{w})$. & $+(8 \mathrm{w})$. & $+(2 \mathrm{y})$. \\
\hline Serum & PCR & $+(2 \mathrm{~d})$. & $-(2 \mathrm{~d})$. & $+(1$ 1/2y. $)$ \\
\hline Buffy coat & PCR & $+(8 \mathrm{w})$. & $+(8 \mathrm{w})$. & $+(2 y)$. \\
\hline
\end{tabular}

PAP = peroxidase-antiperoxıdase; IPX, Immunoperoxıdase; $\mathrm{PCR}$, polymerase chain reaction

n.e. $=$ not examined. ${ }^{*}$ seronegative when 2 days old, ${ }^{* *}$ seropositıve when 2 days old, $* * *$ seronegative at all times tested.

$\mathrm{a} \quad=$ Age when tested: $\mathrm{d}$, days; $\mathrm{w}$, weeks; $\mathrm{y}$, years.

ewes were seropositive at the beginning of the observation period or whether they belonged to the group of ewes that seroconverted during the gestation period of 1989-90. The titres ranged between $1: 10$ and $\geq 1: 1250$ (Table 1 ).

\section{Investigation of cattle herd}

The 5 heifers were in their last month of pregnancy when they rejoined the dairy herd in the spring of 1990. All 5 gave birth to healthy calves. Three months later, in July 1990, the heifers and 3 of their calves ( 2 had been sold) were tested BVDV-antibody positive with titres of $1: 250$ or more. The remaining 70 cows in the herd were at this time still BVDV-antibody negative.

\section{Examination of BD-affected lambs}

Examination of sera collected from the trem- bling twin lambs when 2 days old showed that 1 of them lacked detectable antibodies to $\mathrm{BDV}$, whereas its twin and the dam were antibody positive. Attempts to detect BDV antigens with the IPX technique from sera from these twins failed. However, when using the same technique, virus antigens were detected in buffy coat at 5 and 8 weeks when both lambs were seronegative (Table 2).

With the PCR technique, BDV RNA was found in buffy coat from both lambs and also from serum in the lamb lacking antibodies when 2 days old (Table 2).

Upon hospitalization in June 1990 the 2month old and clinically BD affected twin lambs had signs of pneumonia and a rise in body temperature. The tremors were only noticeable when the lambs were exposed to stress. They were treated with benzylpenicil- 


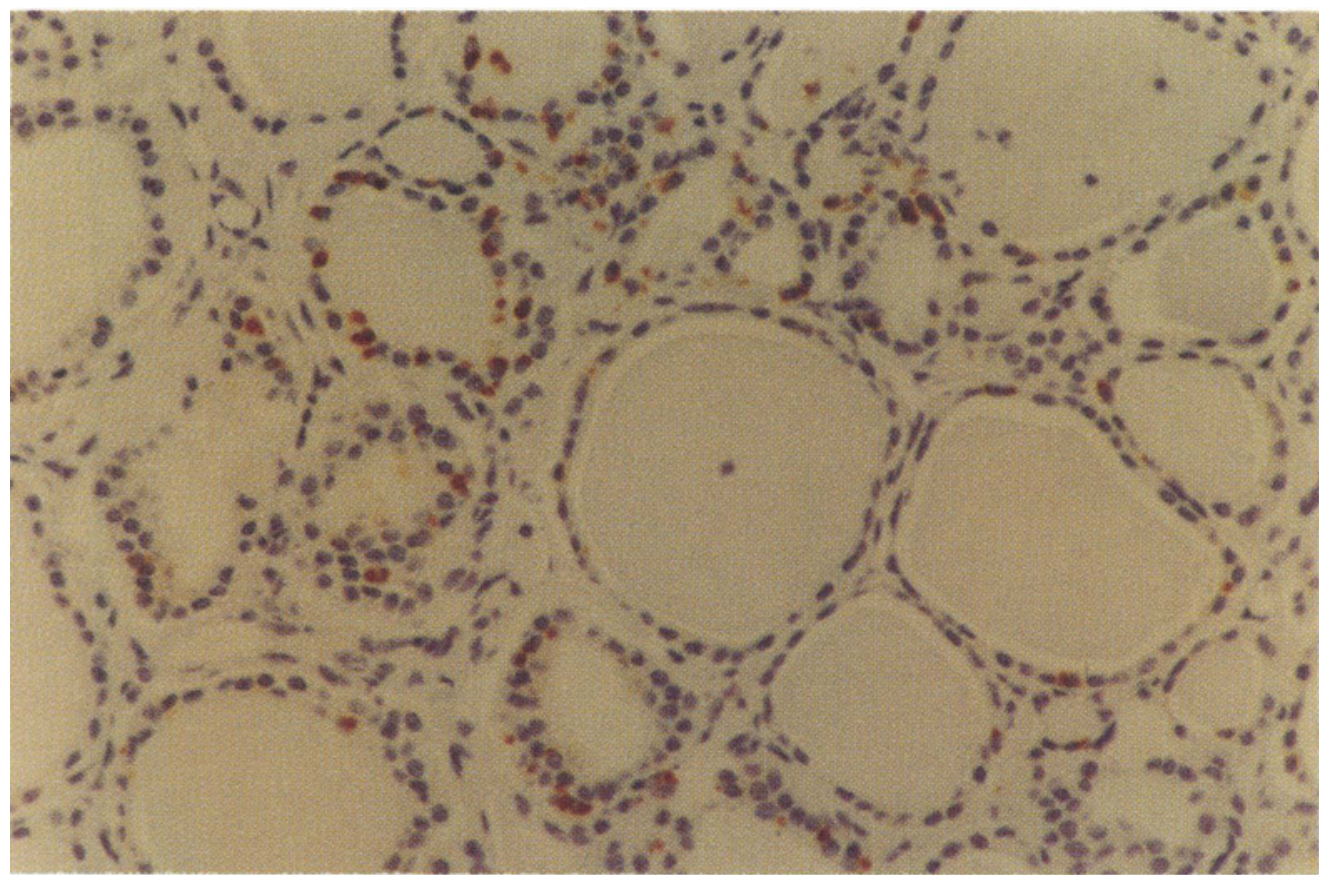

Figure 1. Border disease virus antigens in the cytoplasm of the follicular epithelial cells in thyroidea in a lamb persistently infected with BDV, demonstrated by the peroxıdase-antiperoxidase (PAP) technique using monoclonal antibodies.

lin procaine for 7 days, but since no recovery was noted, they were euthanised shortly thereafter.

Gross post-mortem examination revealed major pneumonic changes in all lung lobes and bacteriological investigations from lung samples revealed growth of pasteurella-like colonies. The histological examination of the central nervous system showed areas of hypomyelination in cerebellum and spinal cord.

Using the PAP technique, 7 different organs were examined and BDV antigens were demonstrated in both lambs in the cytoplasm of the follicular epithelial cells in the thyroid gland (Fig. 1), in neurons in the brain and in the parotid gland. In 1 of the lambs, BDV antigens were also found in the lungs (Table 2).

\section{Examination of ewes A1-A5}

Of the 5 ewes that had been introduced into the flock in the tupping period of 1989, ewe A3 was seronegative to BDV in the spring of 1990 and also found barren. The 4 agematched ewes were seropositive and virus negative and each gave birth to 1 healthy lamb. The same serological status was seen from samples drawn from A1-A5 in November 1989.

Buffy coat and serum from A3 were tested using the IPX technique for BVDV. Only buffy coat was found virus-positive, whereas both serum and buffy coat proved positive for BVDV RNA when using the PCR technique (Table 2). This ewe which had never shown any clinical signs of disease was again tupped 
in the autumn of 1990 and still appeared healthy at the time of euthanasia in February 1991.

Gross post-mortem examination, however, revealed a heavy load of gastro-intestinal parasites, a moderate amount of diffusely spread firm white foci with a diameter of $1 \mathrm{~mm}$ in the myocardium and a mummified fetus in the uterus. The histological examination showed lymphocytic follicles with a few plasma cells in the myocardium, a mild-moderate chronic bronchitis and bronchiolitis, eosinophilic infiltrates in the intestines and diffusely dispersed, small, mononuclear, perivascular infiltrates in the brain.

Tissue samples from A3 from 8 different organs (Table 2) were analysed for BDV antigens by the PAP technique. Only scattered infected follicular epithelial cells of the thyroid gland and neurons in the brain were found to be positive for BDV antigens.

\section{Discussion}

The results of the serologic investigation indicate that the BD infection was introduced by 5 bought-in ewe lambs (A1-A5) during the grazing period to lambs on pasture, and to the remaining flock in the tupping period of 1989. Of these 5 lambs only A3 was seronegative for BDV. In addition, only this lamb was shown to be PI with the virus. It is possible that the ewe that gave birth to A3 was infected during early pregnancy by contact with a PI bull-calf present at the farm where A3 was born. When BDV was introduced into the sheep flock in the autumn of 1989 the spread of the infection was restricted to 7 ewes that seroconverted, all of which had been kept in boxes adjacent to A3. The PI sheep (A3 and the twin lambs) were culled, as were lambs from ewes that seroconverted during the gestation period of 1989-90; the latter was a precautionary measure taken in order to minimize the risk of re- introducing the virus. It was subsequently shown that the BDV infection was controlled, since seronegative ewes and retained lambs remained seronegative even $1 \frac{1}{2}$ years after the outbreak.

The antibody titres to BDV of 1:10 and 1:50 found in older ewes may indicate an infection some years ago (Table 1). The titre obtained in October 1989 in ewe lamb no. 927 might have been a remnant of maternal colostral antibodies. However, antibody titres in those ewes that contracted the infection in 1989-90 were still relatively high (1:250) 2 years after the outbreak. Five of these ewes contracted a transitory infection as lambs, most probably due to contact with A3 in the grazing period of 1989. They developed just as high antibody titres as those that seroconverted during the subsequent pregnancy period, including the dam with BD-affected lambs. It has been suggested, however, that BDV infections in nonpregnant ewes lead to lower antibody titres than in ewes infected in early pregnancy (Sawyer et al. 1986).

The 5 heifers from the BVDV-free dairy herd most probably seroconverted to BVDV during the period they spent in the sheep flock when 6-8 months pregnant, but the exact time when they became infected during this period cannot be stated. That the infection occurred in late pregnancy is strengthened by the high antibody titres $(\geq 1: 250)$ found in their 3month old calves. This would indicate that the calves were infected in utero when immunocompetence had already been gained since, in our experience, maternally derived antibodies found in calves at this age are usually lower (1:10-1:50) and sometimes no longer detectable. Passively derived BVDV antibodies in calves PI have usually disappeared at an age of 2 months (Palfi et al. 1993).

We conclude that since other cattle in the herd remained seronegative after the 5 heifers had 
returned, neither these heifers, nor their calves, passed on the virus after a recent transient BVDV-infection in late pregnancy.

The pathological findings in autopsied animals, such as the lung lesions or the heavy load of gastro-intestinal parasites in ewe A3, are not uncommon in PI animals and are referred to as an increased susceptibility to infections (Terpstra 1985, Barber et al. 1985). Myocardial lesions were also observed in A3 and have been described in BDV infected goat kids (Löken et al. 1990). Myocarditis and pneumonia have also been reported in adult PI sheep (Jeffrey \& Roeder 1987).

The demonstration of BDV antigens based on the IPX was verified in organs or blood samples, with PAP and PCR techniques, respectively. The positive PCR results indicate that the primers selected from the BVDV genome were able to amplify BDV sequences in the present experiment. To our knowledge, this is the first report on PCR detection of BDV. It was also shown that BDV antigens are likely to be found in the brain and thyroid gland using the PAP technique. Negative results were encountered in the detection of antigens from sera using the IPX technique, an observation also made by others (Lees et al. 1991). However, when buffy coat was examined, both the affected twin lambs and $A 3$ were found to be $\mathrm{BDV}$ positive. Attempts to re-isolate antigens from $\mathrm{A} 3$ using the same technique did not succeed. A recent report demonstrated that half as many peripheral blood lymphocytes $(10 \%)$ are infected with virus in PI adult sheep as in PI lambs (22\%) (Woldehiwet \& Hussin 1992). This might account for the difficulties encountered in virus isolation from A3. However, it should be emphasized that with the PCR technique, viral RNA was detected in the buffy coat specimen as well as in the serum of ewe A3. This finding, which is similar to the result with the serum specimen from 1 of the twin lambs, indicates that the PCR may detect the virus in clinical specimens when IPX fails.

This study has shown that an infection with BDV can be controlled, provided that an early diagnosis is made and adequate measures are taken. These must include removal of all diagnosed and suspected PI animals. In addition, as a result of increased knowledge of the epidemiology of BVDV/BDV, precautions in order to reduce the risk of transmission of the infection between herds should be taken. Introduction of animals with unknown BVDV/BDV status into virus-free herds should be avoided. To avoid transmission of a transient infection, the introduced animal should be placed in quarantine for at least 4 weeks and if it is both pregnant and has an antibody titre to the virus it should be kept isolated until its offspring has been shown not to be a virus carrier.

\section{Acknowledgements}

Pathologists M. Elvander and C. Hård af Segerstad are thanked for assistance by performing the autopsies. The authors also wish to thank Dr. S. Alenius for helpful critıcism. Drs. S. Belák, A. BallagiPordány and Ms. A. Persson are thanked for their work with the PCR analysis. The laboratory help of Ms. M. Hjort and Ms. E. Westergren is gratefully acknowledged. This work received financial support by grants from the Swedish Council for Forestry and Agricultural Research.

\section{References}

Barber DML, Nettleton PF, Herring JA: Disease in a dairy herd associated with the introduction and spread of bovine virus diarrhoea virus. Vet. Rec. 1985, 117, 459-464.

Barlow RM, Vantsıs JT, Gardıner AO, Rennie JC, Herring JA, Scott FMM $\cdot$ Mechanısm of natural transmission of Border disease. J. comp. Pathol. 1980, 90, 57-65.

Belák K, Gimeno EJ, Belák S. Demonsstration of bovine viral diarrhoea virus antigens in cell cultures and in paraffin-embedded tissue sections by the peroxidase-antıperoxidase (PAP) tech- 
nique using monoclonal antıbodies. Acta vet. scand. 1989, 30, 231-233.

Belák S, Ballagı-Pordány A· Bovine viral diarrhea virus infection rapid diagnosis by the polymerase chain reaction. Arch. Virol. 1991, (Suppl. 3), 181-190.

Berry ES, Lewis TL, Ridpath JF, Evermann JF, Rupnow $B A, Q \imath F$. Genomic comparison of ruminant pestıviruses. 2nd symposium on rumınant pestıviruses, Annecy, France, 1-3 Oct 1992, p. 53.

Carlsson $U$. Border disease in sheep caused by transmission of virus from cattle persistently infected with bovine virus diarrhoea virus Vet. Rec. 1991, 128, 145-147.

Franckl RI, Fanquets CM, Knudson DL, Brown F: Classification and nomenclature of viruses. Arch. Virol. 1991 (Suppl. 2), 223-233.

French EL, Hore DE, Snowdon WA, Parsonson IM, Uren J. Infection of pregnant ewes with mucosal disease virus of ovine origin. Aust. vet J. 1974, $50,45-54$.

Hughes LE, Kershaw GF, Shaw IG. "B" or border disease. An undescribed disease of sheep. Vet. Rec. 1959, 71, 313-317.

Jeffrey $M$, Roeder $P L \cdot$ Variable nature of border disease on a single farm: Clinical and pathological description of affected sheep. Res. vet. Sci. 1987, 43, $22-27$.

Juntt N, Larsson B, Fossum C The use of monoclonal antıbodies in enzyme linked immunosorbent assays for detection of antibodies to bovine viral diarrhoea virus J. vet. Med. 1987, B 34, 356-363.

Lees $V W$, Loewen KG, Deregt $D$, Knudsen $R \cdot$ Isolation of border disease virus from twin lambs in Alberta. Can Vet. J. 1991, 32, 678-682.

Lundén A, Carlsson $U$, Naslund $K \cdot$ Toxoplasmosis and border disease in 54 Swedish sheep flocks: Seroprevalence and incidence during one gestation period. Acta vet scand. 1992, 33, 175-184.

Loken T, Bjerkås I, Larsen HJ: Experımental pest1virus infections in newborn goat kids. J. comp. Pathol. 1990, 103, 277-288

Loken T, Krogsrud J, Bjerkås I: Outbreaks of border disease in goats induced by a pestıvirus contaminated orf vaccine, with virus transmission to sheep and cattle. J. comp. Pathol. 1991, 104, 195209.

Meyling A: Detection of BVD virus in viremic cattle by an indirect immunoperoxidase technique. In: M.S McNulty \& J.B. McFerRan (eds): Recent advances in virus diagnosis. Boston, Martınus Nijhoff, 1984, pp. 37-46.
Moerman A, Straver PJ, de Jong MCM, Quak J, Baanvinger Th. van Otrschot JT: A long term epidemiological study of bovine viral diarrhoea infections in a large herd of dairy cattle. Vet. Rec. 1993, 132, 622-626.

Nettleton PF. Border disease update. Vet Rec. suppl.: In Practice, 1988, 10, 76.

Palfi V, Houe H, Philipsen J: Studies on the decline of bovine virus diarrhoea virus (BVDV) maternal antibodies and detectability of BVDV in persistently infected calves. Acta vet. scand. 1993, 34, 105-107.

Physick-Sheard PW, Hopkıns JB, O'Connor RD. A border disease-like syndrome in a southern Ontario sheep flock. Can vet. J 1980, 21, 53-60.

Sawyer MM, Schore CE, Menzles PI, Osburn BI. Border disease in a flock of sheep: Epıdemıologic laboratory and clinical findings. J. Amer. vet. med. Ass. 1986, 189, 61-65.

Tarry DW, Bernal L, Edwards S: Transmission of bovine virus diarrhoea virus by blood feeding flies Vet. Rec. 1991, 128, 82-84.

Terpstra $C$ Border disease: a congenital infection of small ruminants. Progress in vet. microbiol. and Immunol. In: Pandey R, Karger S, (eds): Infection and immunity in farm anımals. Basel 1985 , p 175.

Woldehiwet Z, Nettleton PF. Progeny of sheep persistently infected with border disease virus. Arch. Virol. 1991, (Suppl. 3), 267-271.

Woldehiwet $Z$, Hussin AA . Demonstration of border disease virus in lymphocyte subsets of persistently infected sheep. 2nd symposium on rum1nant pestıviruses. Annecy, France, 1-3 Oct 1992, p 100.

\section{Sammanfattning.}

Smittoverforıng av border disease virus till får och not via en persistent infekterad tacka. epıdemiologi och kontroll

I en svensk fårbesattnıng om 215 djur konstaterades under lamnıngsperıoden 1990 ett par tvillınglamm vara persistent infekterade med border disease virus (BDV). Serologiska respektıve virologiska undersoknıngar indıkerade att viruset hade introducerats med en med BDV persistent infekterad tacka vilken inkopts under foregående betacknıngssasong. Endast 7 tackor, vilka alla hade haft narkontakt med 
det inkopta fåret, serokonverterade under efterfoljande draktighetsperıod. Två av dessa gick gall. Lamm från de ovriga 5 tackorna inklusive persistent infekterade djur slogs ut. Smittspridningen kontrollerades darmed och inga ytterligare djur serokonverterade $i$ fårbesattningen.

Under samma period serokonverterade sannolıkt àven 5 kvigor 1 sent draktıghetsstadie mot bovint v1rus diarre virus (BVDV). Dessa var tillfalligt inhysta 1 fårbesattnıngen och hade haft kontakt med den inkopta tackan under månaderna januar1-mars 1990. Nar kvigorna återforenats med den BVDV-frıa mjolkkobesattning de ursprungligen kommit ıfrån hade de utvecklat hoga antikroppstitrar mot BVDV Detta noterades aven hos deras kalvar. Varken kv1gorna, vilka smittats under sen draktıghet, eller deras kalvar, fororsakade någon spridning av BVDV då de ovriga 70 korna 1 besättningen forblev seronegativa.

Undersoknningen visar att 1 kontrollen av BDV hos får och BVDV hos not ar det aven viktıgt att mınımera riskerna av overföring av BDV/BVDV mellan dessa bagge djurslag.

(Recelved July 20, 1993; accepted November 22, 1993).

Reprınts may be requested from: U Carlsson, Department of Cattle and Sheep Divisıon, Swedish Unıversity of Agricultural Sciences, S-750 07 Uppsala, Sweden. 